\title{
HUBUNGAN PENGETAHUAN DAN PERILAKU PASIEN TENTANG PENATALAKSANAAN DIABETES MELLITUS DI BANJARBARU KALIMANTAN SELATAN
}

\author{
Rika Meldy Agustina, Noor Diani, Agianto \\ Program Studi Ilmu Keperawatan, Fakultas Kedokteran, Universitas Lambung Mangkurat, Jl. A. Yani KM. 36 Banjarbaru, 70714
}

Correspondence author:

\section{Rika Meldy Agustina}

Program Studi Ilmu Keperawatan, Fakultas Kedokteran, Universitas Lambung Mangkurat, Jl. A. Yani KM. 36 Banjarbaru, 70714 Email: rikameldyagustina@gmail.com

\section{Article Info:}

Received: 22 January 2019

Revised: 17 June 2019

Accepted: 23 June 2019

Available online: 31 July 2019

Keywords: Knowledge,

Behavior, Treatment DM

DOI: $10.20956 / n m s j . v 4 i 1.5955$

\begin{abstract}
Introduction: In patients with type 2 diabetes mellitus (DM), sufficient knowledge and behavior are important for adherence to the lifelong treatment. The aim of this study is to measure the correlation between knowledge and behavior about the treatment of DM in diabetic patients in Kelurahan Cempaka. Methods: This is a cross-sectional study using a simple random sampling technique, with a total of 60 participants. We used a questionnaire on patients' knowledge and behavior pertaining the treatment of type $2 \mathrm{DM}$.

Result: From this study, we found that there is a significant correlation between knowledge and behaviour regarding the treatment in patients with type $2 \mathrm{DM}$ $(\mathrm{p}<0.001)$.

Conclusion: Knowledge has an important role in tailoring people's behavior to carry out appropriate treatment in order to optimize the health status.
\end{abstract}

\section{PENDAHULUAN}

Diabetes mellitus (DM) merupakan suatu kelompok penyakit metabolik dengan karakteristik hiperglikemia (peningkatan kadar glukosa darah) yang terjadi karena kelainan pada sekresi insulin, kerja insulin, atau kedua-duanyal. Pada tahun 2013, terdapat 382 juta orang yang menderita DM di seluruh dunia 1. Pada tahun 2035 jumlah penderita tersebut diperkirakan akan meningkat menjadi 592 juta orang. Kementerian kesehatan RI tahun 2014 menyatakan di Indonesia terjadi peningkatan penderita DM dari $1,1 \%$ ditahun 2007 menjadi 2,1\% ditahun 201317. Pada tahun 2015, Indonesia menempati urutan ke-7 teratas di dunia dengan jumlah penderita diabetes sebanyak 9,1 juta jiwa. Di Kalimantan Selatan, prevalensi DM diperkirakan sekitar 38.113 $(1,4 \%)$ jiwa dari total penduduk berumur $>14$ tahun 2. Data kunjungan pasien se-Banjarbaru berjumlah 1081 kunjungan pada tahun 201718 .

Kenaikan prevalensi DM tipe 2 secara global ternyata disebabkan karena kurangnya pengetahuan mengenai penatalaksanaan diabetes dan perubahan gaya hidup, seperti perilaku yang kurang sehat, kegemukan, dan kurang olahraga4. Pengetahuan atau kognitif merupakan domain yang sangat penting untuk terbentuknya tindakan atau perilaku seseorang. Pengetahuan penderita diabetes sangatlah penting dalam menentukan perilaku yang dapat mengurangi risiko terjadinya komplikasi. Apabila pengetahuan penderita mengenai diabetes baik, maka perilaku penderita terhadap penatalaksanaan pun akan baik4.

Studi terdahulu menunjukkan rendahnya pengetahuan tentang penyebab, gejala, pengaturan diet, latihan fisik, pemantauan gula darah dan pencegahan komplikasi pada DM. 
Komplikasi yang sering terjadi pada pasien DM antara lain penyakit jantung koroner, ginjal, kebutaan, aterosklerosis, dan bahkan ada anggota tubuh yang bisa diamputasi akibat kematian jaringan yang membusuk. Berdasarkan uraian di atas, maka penulis tertarik untuk meneliti pengetahuan dan perilaku tentang penatalaksanaan DM pada pasien diabetes di Kota Banjarbaru, Kalimantan Selatan.

\section{METODE PENELITIAN}

Penelitian menggunakan rancangan deskriptif dengan metode cross sectional. Teknik sampling yang digunakan adalah simple random sampling, dengan total sampel yaitu 60 responden. Penelitian ini dilakukan pada bulan Desember 2018 di Kelurahan Cempaka. Instrumen yang digunakan dalam penelitian adalah kuesioner mengenai karakteristik demografi, pengetahuan, dan perilaku penatalaksanaan DM. Analisis uji statistik yang digunakan adalah Fisher exact test $(\alpha<0.05)$ dan sudah mendapatkan kelayakan etik dari Fakultas Kedokteran Universitas Lambung Mangkurat dengan nomor surat No.1066/KEPKFKUNLAM/EC/XII/2018.

\section{HASIL DAN PEMBAHASAN}

\section{Karakteristik Responden}

Rata-rata usia responden pada penelitian ini adalah 53,7 tahun, dan rata-rata menderita diabetes selama 4,4 tahun. Berdasarkan usia, kejadian DM sering muncul setelah usia lanjut terutama setelah berusia 40 tahun $^{6}$. Hasil penelitian ini didukung oleh pernyataan WHO yang menyatakan bahwa setelah seseorang berusia lebih dari 30 tahun, maka kadar gula darah akan meningkat 1-2 mg/dL/tahun pada saat puasa 7 .

Tabel 1 menunjukkan profil demografis pasien DM yang terlibat pada penelitian ini. Mayoritas $(71,7 \%)$ responden adalah perempuan. Prevalensi diabetes pada perempuan lebih tinggi daripada laki-laki, hal ini dikarenakan beberapa faktor risiko seperti kegemukan (obesitas), kurangnya aktivitas atau latihan fisik, usia, dan riwayat DM terdahulu ${ }^{2}$.
Tabel 1 Karakteristik Responden Penelitian di Kelurahan Cempaka Bulan Desember Tahun $2018(n=60)$

\begin{tabular}{lcc}
\hline \multicolumn{1}{c}{ Karakteristik } & $\begin{array}{c}\text { Frekuensi } \\
\text { Responden }\end{array}$ & Persentase (\%) \\
\hline Jenis Kelamin & & \\
Laki-laki & 17 & $28,3 \%$ \\
Perempuan & 43 & $71,7 \%$ \\
\hline $\begin{array}{l}\text { Penyakit Penyerta } \\
\text { Tidak ada }\end{array}$ & 14 & $21,7 \%$ \\
Ada & 46 & $78,3 \%$ \\
\hline Tingkat Pendidikan & & \\
Tidak sekolah & & \\
SD & 17 & $28,4 \%$ \\
SMP & 27 & $45,0 \%$ \\
SMA & 8 & $13,3 \%$ \\
PT & 5 & $8,3 \%$ \\
& 3 & $5,0 \%$ \\
\hline \multicolumn{2}{c}{} \\
\hline Karakteristik & Frekuensi & Persentase \\
& Responden & $(\%)$ \\
\hline Pekerjaan & & \\
PNS & 2 & $3,3 \%$ \\
Petani & 3 & $5,0 \%$ \\
Pedagang & 11 & $18,3 \%$ \\
Lain-lain & 44 & $73,3 \%$ \\
\hline
\end{tabular}

Sebanyak 46 responden $(78.3 \%)$ memiliki penyakit penyerta (ko-morbid). Hasil penelitian ini sejalan dengan penelitian oleh Chiptarini (2014) yang menunjukkan bahwa mayoritas pasien DM memiliki penyakit penyerta, yaitu hipertensi sebanyak 31 orang $(53,4 \%)$ dari 60 responden ${ }^{8}$. Dari segi pendidikan, sebagian besar (45\%) responden berpendidikan SD (Sekolah Dasar). Terdapat hubungan antara tingkat pendidikan dengan kejadian DM, dimana seseorang dengan tingkat pendidikan rendah memiliki resiko 1,27 kali lebih tinggi untuk menderita DM dibandingkan dengan orang yang berpendidikan tinggi. Seseorang dengan tingkat pendidikan rendah pada umumnya memiliki pengetahuan yang minim mengenai gaya hidup sehat dan penyebab penyakit kronis, termasuk DM. Semakin tinggi pendidikan seseorang semakin besar kepeduliannya terhadap kesehatan ${ }^{9}$.

Dari populasi studi kami, sebagian besar $(73,7 \%)$ responden adalah Ibu Rumah Tangga atau tidak bekerja. DM banyak terjadi pada ibu rumah tangga dikarenakan beberapa faktor peneyabab, diantaranya gaya hidup yang kurang sehat, kurangnya pengetahuan mengenai penyakit ini, penatalaksanaan diabetes yang tidak dipatuhi, dan kurangnya melakukan latihan fisik atau olahraga ${ }^{10}$. 


\section{Pengetahuan}

Tabel 2 Pengetahuan Pasien Diabetes Mellitus di Kelurahan Cempaka Bulan Desember Tahun $2018(\mathrm{n}=60)$

\begin{tabular}{ccc}
\hline Karakteristik & Frekuensi (f) & Persentase (\%) \\
\hline Pengetahuan & & \\
Baik & 23 & $38.3 \%$ \\
Kurang & 37 & $61.7 \%$ \\
\hline
\end{tabular}

Dari Tabel 2, diketahui bahwa sebagian besar $(61,7 \%)$ pasien DM memiliki pengetahuan yang kurang mengenai penyakitnya. Hal penting mengenai diabetes seperti penyebab, diet, aktivitas fisik, dan pengobatan tidak diketahui oleh pasien, sehingga dalam melakukan penatalaksanaannya pasien tidak melakukan sesuai dengan anjuran. Pada saat penelitian, kami temukan bahwa pasien tidak mendapatkan pendidikan, penyuluhan, ataupun informasi mendasar yang diperlukan mengenai penyakit yang diderita.

\section{Perilaku}

Tabel 3 Perilaku pada Pasien Diabetes Mellitus di Kelurahan Cempaka Bulan Desember Tahun $2018(\mathrm{n}=60)$

\begin{tabular}{lcc}
\hline Karakteristik & Frekuensi (f) & Persentase (\%) \\
\hline Perilaku & & \\
Baik & 10 & $16,7 \%$ \\
Kurang & 50 & $83.3 \%$ \\
\hline
\end{tabular}

Dari Tabel 3, didapatkan bahwa dari sebanyak 50 responden $(83.3 \%)$ memiliki perilaku yang kurang terhadap penatalaksanaan diabetes.

Pada saat penelitian, pasien mengaku tidak tahu-menahu mengenai penyakit yang diderita, sehingga tidak patuh dalam melakukan penatalaksanaan yang dianjurkan. Perilaku seperti diet, olahraga dan latihan fisik, pemantauan kadar gula darah, dan perawatan kaki sangat jarang dilakukan oleh pasien dalam penatalaksanaan penyakitnya.

Perilaku kesehatan merupakan suatu respon terhadap stimulus atau obyek yang berkaitan dengan sakit dan penyakit ${ }^{5}$. Perilaku penderita yang diharapkan adalah mengikuti pola makan yang sehat, meningkatkan kegiatan jasmani (olahraga), menggunakan obat diabetes dalam keadaan khusus secara aman, teratur dan sesuai anjuran, melakukan pemantauan kadar gula darah secara mandiri, dan mampu memanfaatkan fasilitas pelayanan kesehatan yang $\operatorname{ada}^{3}$.

\section{Hubungan Pengetahuan dengan Perilaku}

Tabel 4 Hubungan Pengetahuan dan Perilaku tentang Penatalaksanaan Diabetes Mellitus di Kelurahan Cempaka Bulan Desember Tahun $2018(\mathrm{n}=60)$

\begin{tabular}{|c|c|c|c|c|c|c|c|}
\hline \multirow{3}{*}{$\begin{array}{l}\text { Penge } \\
\text { tahuan }\end{array}$} & \multicolumn{4}{|c|}{ Perilaku } & \multirow{2}{*}{\multicolumn{2}{|c|}{ Total }} & \multirow{3}{*}{$\begin{array}{c}\text { p- } \\
\text { valu } \\
\text { e }\end{array}$} \\
\hline & \multicolumn{2}{|c|}{ Baik } & \multicolumn{2}{|c|}{ Kurang } & & & \\
\hline & $\mathbf{n}$ & $\%$ & n & $\%$ & n & $\%$ & \\
\hline Baik & 9 & $\begin{array}{c}39, \\
1\end{array}$ & 14 & $\begin{array}{c}60 \\
9\end{array}$ & 23 & 100 & $<0,0$ \\
\hline $\begin{array}{c}\text { Kuran } \\
\text { g }\end{array}$ & 1 & 2,7 & 36 & $\begin{array}{c}97, \\
3\end{array}$ & 37 & 100 & 01 \\
\hline
\end{tabular}

Tabel 4 menunujukkan hubungan antara pengetahuan dan perilaku tentang penatalaksanaan DM. Dari penelitian ini, kami menemukan adanya hubungan yang signifikan $(\mathrm{p}<0.001)$ antara pengetahuan dan perilaku tentang penatalaksanaan DM pada pasien diabetes .

Dengan adanya edukasi (pembelajaran), manusia dapat mengembangkan apa yang diketahui dan dapat mengatasi kebutuhan untuk kelangsungan hidupnya, sehingga akan mempengaruhi seseorang dalam berperilaku ${ }^{12}$. Masyarakat Indonesia perlu mendapatkan informasi atau penyuluhan kesehatan yang memadai mengenai DM tipe 2. Misalnya seseorang yang memiliki riwayat keluarga positif menderita DM, maka pencegahan dini terhadap kenaikan kadar gula darah harus lebih diperhatikan ${ }^{13}$.

Dari penelitian kami, didapatkan 37 orang $(61,7 \%)$ berpengetahuan kurang. Hal ini sejalan dengan penelitian Kong, Yein dan Jenn (2012) yang menyimpulkan bahwa kurangnya pengetahuan tentang DM menyebabkan penderita cenderung untuk tidak mematuhi pengobatan, diet, dan insulin secara tepat ${ }^{14}$. Informasi dan penyuluhan kesehatan yang diberikan kepada penderita meliputi pemahaman mengenai perjalanan penyakit, diet atau anjuran makan yang diperbolehkan untuk dikonsumsi, latihan fisik yang dianjurkan, penggunaan obat-obatan sesuai dosis, perlunya pengendalian dan pemantauan kadar gula darah secara regular, serta perawatan kaki yang baik agar tidak terjadi komplikasi ulkus diabetik $^{3}$.

Pengetahuan mengenai diet merupakan suatu hal yang penting untuk dapat mengembangkan rutinitas (kebiasaan) yang dapat 
membantu penderita dalam mengikuti anjuran diet yang sesuai. Penderita yang tidak patuh dalam menjalankan diet dapat menyebabkan kadar gula yang tidak tekendali. Diet yang dianjurkan diperoleh dari karbohidrat, lemak, dan protein. Hasil penelitian ini sejalan dengan penelitian oleh Prabowo (2014) yang menyatakan masih banyak penderita DM yang tidak patuh dalam berperilaku diet sesuai dengan anjuran ${ }^{15}$.

Pengetahuan mengenai pentingnya pemantauan kadar gula darah secara rutin dan mandiri dapat membantu pasien dalam mengatur terapinya, sehingga pengendalian kadar gula darah dapat dilakukan secara optimal. Kadar gula darah yang meningkat melebihi batas normal pada diabetes dapat menimbulkan berbagai komplikasi kardiovaskuler seperti penyakit jantung koroner, penyumbatan pembuluh darah perifer, gangren diabetik, nefropati diabetic, dan katarak. Salah satu cara yang bisa dilakukan oleh penderita adalah mengontrol kadar gula darah tersebut agar tetap stabil dan tidak melebihi batas normal ${ }^{16}$.

\section{KESIMPULAN DAN SARAN}

\section{Kesimpulan}

Dari penelitian ini, kami menyimpulkan bahwa ada hubungan yang bermakna antara pengetahuan dan perilaku pasien mengenai penatalaksanaan DM. Pada penelitian ini juga dapat disimpulkan bahwa dalam memberikan edukasi mengenai penatalaksanaan diabetes, tenaga kesehatan haruslah mempertimbangkan latar belakang pendidikan pasien. Pada umumnya mereka yang menderita DM memiliki tingkat pendidikan dan sosio-ekonomi yang rendah, sehingga psikoedukasi baik aktif maupun pasif harus dilakukan menggunakan bahasa awam dan mudah dimengerti.

\section{Saran}

Diharapkan bagi pelayanan keperawatan dapat memberikan penyuluhan kesehatan dengan metode berbeda seperti ceramah atau demonstrasi agar dapat meningkatkan pengetahuan dan perilaku pasien mengenai penyakit terutama DM dalam penatalaksanaannya.

\section{KEPUSTAKAAN}

1. International Diabetes Federation (IDF), 2013, IDF Diabetes Atlas Sixth Edition.

2. Riset Kesehatan Dasar (Riskesdas), 2013, Jakarta, Balitbang Kemenkes RI.

3. Perkeni, 2006, Konsensus Pengelolaan dan Pencegahan bagi Penyandang Diabetes, Jakarta, PERKENI.

4. Waspadji, 2007, Manajement Hidup sehat Diabetes Mellitus, Jakarta, Balai Penerbit FKUI.

5. Notoatmodjo, S, 2015, Promosi Kesehatan dan Ilmu Perilaku, Jakarta, Rineka Cipta .

6. Hadibroto, dkk, 2010, Diabetes: Informasi lengkap untuk penderita dan keluarganya, Jakarta, Gramedia Pustaka.

7. World Health Organization (WHO), 2011, Definition and diagnosis of diabetes mellitus and intermediate hiperglycaemia, Report of WHO/IDF Consultation 2011.

8. Chiptarini, Ika F,.D, 2014, Gambaran Pengetahuan dan Perilaku tentang Penatalaksanaan DM pada Pasien DM di Puskesmas Ciputat Timur, Jakarta, Universitas Islam Negeri Syarif Hidayatullah.

9. Irawan, D, 2010, Prevalensi dan Faktor Risiko Kejadian Diabetes Melitus Tipe 2 di Daerah Ubran Indonesia (Analisa Data Sekunder Riskesdas 2007), Tesis, Jakarta, Fakultas Kedokteran Masyarakat Indonesia.

10. Wicaksono, 2013, Diabetes Melitus Tipe 2 Gula Darah Tidak Terkontrol dengan Komplikasi Neuropati Diabetikum, Jurnal Medula, 1(3): 10-17.

11. Waspadji, 2009, Komplikasi Kronik Diabetes: Mekanisme Terjadinya, Diagnosis dan Strategi Pengelolaan, In: Buku Ajar Ilmu Penyakit Dalam, Jilid III, Edisi IV, Jakarta, Interna Pubslishing 1922-1926.

12. Karyoso, 2003, Pengantar Komunikasi Perawat, Jakarta, EGC.

13. Sidartawan, S, 2009, Diagnosa dan Klasifikasi Diabetes Melitus Terkini dalam Penatalaksanaan Diabetes Melitus Terpadu, Jakarta, Rineka Cipta. 
14. Kong, Yein \& Jenn, 2012, Psychological insulin resistance: Patient beliefs and implications for diabetes management, Quality life search, Vol.18, 22-23.

15. Prabowo, A \& Hastuti, W, 2014, Hubungan pendidikan dan dukungan keluarga dengan kepatuhan diit pada penderita diabetes mellitus di Wilayah Puskesmas Plosrejo Giribangun Mateshih Kabupaten Karanganyar, Karya Tulis Diploma III, Surakarta, STIK Surakarta.
16. Sugiarto, B.R \& Suprihatin, 2012, Kepatuhan Kontrol dengan Tingkat Kadar Gula Darah Pasien Diabetes Melitus di Rumah Sakit Baptis Kediri, Jurnal Stikes, 5(2), 213-222.

17. Kementerian Kesehatan RI, 2014, Profil Kesehatan Indonesia, Jakarta, Kemenkes RI.

18. Dinas Kesehatan Kota Banjarbaru, 2017, Data Kunjungan Pasien se-Banjarbaru, Banjarbaru, Dinkes BJB. 